\title{
Two New Species of Opiliones from Southern Siberia and Mongolia, with an Establishment of a New Genus and Redefinition of the Genus Homolophus
}

(Arachnida: Opiliones: Phalangiidae)

\author{
Nobuo Tsurusaki ${ }^{1}$, Aleksey N. Tchemeris ${ }^{7}, \&$ Dmitri V. Logunov ${ }^{3}$ \\ ${ }^{1}$ Laboratory of Biology, Department of Environmental Sciences, Faculty of Education and \\ Regional Sciences, Tottori University, Tottori, 680-8551 Japan \\ E-mail: ntsuru@fed.tottori-u.ac.jp \\ ${ }^{2}$ Department of Invertebrate Zoology, Faculty of Biological and Soil Sciences, Tomsk State \\ University, Leninsky prospekt 36, Tomsk, 634010, Russia \\ E-mail: opil @ bio.tsu.ru \\ ${ }^{3}$ Zoological Museum, Biological Institute of the Siberian Division of the Russian Academy of \\ Sciences, Frunze Str. 11, Novosibirsk, 630091, Russia \\ E-mail: dpavuk@online.nsk.su
}

\begin{abstract}
Two opilionid species of Phalangiinae (Phalangiidae), Acanthomegabunus sibiricus n. gen. and n. sp., and Homolophus gobiensis n. sp. are described from southern Siberia, Russia, and Mongolia, respectively. A refined diagnosis of the genus Homolophus is presented. Phalangium pallens Kulczynski is resurrected and placed under Homolophus. Homolophus potanini is removed from the genus and is placed provisionally in the genus Opilio. Opilio asiaticus Gricenko 1979 is first synonymized with Opilio potanini (Simon 1895).
\end{abstract}

Key words - Acanthomegabunus sibiricus, Homolophus, Mongolia, new genus, new species, Opiliones, Siberia

As our fist attempt to accumulate the knowledge on opilionid fauna of Siberia and adjacent areas, we have reported on occurrence of eight species and redescribed some poorly-known species among them (Tchemeris et al. 1998). During the extensive faunal survey, from which materials used in the article were yielded, two undescribed species were also obtained. In this paper, we describe the two species belonging to the subfamily Phalangiinae of the family Phalangiidae: one from the mountains of South Siberia as Acanthomegabunus sibiricus n. gen. and n. sp. and another from Mongolia as Homolophus gobiensis n. sp. In addition, some errors inadvertently occurred in our first paper are amended, and a minor revision of the genus Homolophus and related species is presented.

Abbreviations used: ISE - Zoological Museum, Institute for Systematics and Ecology of Animals, Novosibirsk, Russia, D. V. Logunov; SMF - Senckenberg Museum, Frankfurt, M. Grasshoff; TUJ - Department of Biology, Faculty of Education, Tottori Univ., Tottori, Japan, N. Tsurusaki; ZMU - Zoological Museum of the Moscow State University, Moscow, Russia, K. G. Mikhailov; $\mathrm{Fe}=$ femur, $\mathrm{Pa}=$ patella, $\mathrm{Ti}=$ tibia, $\mathrm{Mt}=$ metatarsus, $\mathrm{Ta}=$ tarsus. 


\author{
Family Phalangiidae \\ Subfamily Phalangiinae \\ Acanthomegabunus n. gen.
}

Type species. Acanthomegabunus sibiricus n. sp.

Diagnosis. Most similar to Megabunus Meade 1855 from western Europe (Martens 1978), but differs from it by: 1) lacking long ventral spines of palpal trochanter (Fig. 3B-C); 2) having palpal patellae dorsally with a row of conspicuous spines (Fig. 3B-C); and 3) having legs with five to six longitudinal rows of erected spines.

Description. Medium-sized opilionids with soft, smooth bodies except for presence of a transverse row of several minute tubercles on each abdominal tergite and a few scattered teeth on cephalothorax. Ocular tubercle, huge and high, and with numerous long spines. Chelicera normal, without a ventral tooth on basal joint; movable finger without apophysis. Supracheliceral lamellae not developed, invisible from above. Scent gland pores visible from above. Palpi with ditomesal apophyses on patellae and tibiae; femora distomesally with a knob-like process bearing several bristles; tarsi of males with a ventromesal row of denticles, unarmend in females; femora to tibiae dorsolaterally and ventrally with three rows of conspicuous spines; palpal claw untoothed. Legs relatively short; trochanter to metatarsus with a row (metatarsi) or five longitudinal rows (femur to tibiae) of erected spines. Penis dorso-ventrally flattened, a bundle of muscles occupies basal three fifths of shaft.

Etymology. The name of the genus is masculine and derived from Greek, akantha (thorn) + mega (large) + bounos (bump or mound). It represents general resemblance to the European genus Megabunus and thorny ocular tubercle, palpi and legs.

\title{
Acanthomegabunus sibiricus $\mathrm{n}$. $\mathrm{sp}$.
}

(Figs. 1-4)

Specimens examined. Holotype: male (ISE), KRASNOYARSK PROVINCE, RUSSIA, Ermakovskoye District, West Sayany Mts., $2-3 \mathrm{~km} \mathrm{~N}$ of Aradan, Beliy Us River Valley [52 $36^{\prime} \mathrm{N}, 9^{\circ} 27^{\prime} \mathrm{E}$ ], 840-850 m a.s.1, 8/9-VII-1990 (D. V. Logunov).

Paratypes: 2 males, 3 females (ISE), 2 males, 1 females (TU) together with holotype; 2 females (ISE), 1 female (TUJ), same province and district, West Sayany Mts., Kurtushibinskiy Mt. Range, 8-10 km NW of Shiviligh [ $52^{\circ} 14^{\prime} \mathrm{N}, 93^{\circ} 28^{\prime} \mathrm{E}$ ], 5-VII-1990 (D. V. Logunov). - KHAKASSIA. Shyra District: 1 male (ISE), $1 \mathrm{~km} \mathrm{~N}$ of Kommunar [54 $17^{\prime} \mathrm{N}, 9^{\circ} 18^{\prime} \mathrm{E}$ ], 1300-1400 m a.s.1, 23-VII-1990 (D. V. Logunov), 4 males (ISE), SE part of Abakansky Mt. Range sytem, Choochek Mt. Range, ca. $20 \mathrm{~km}$ SSE of Mrassu Vil. [51 $13^{\prime} \mathrm{N}, 83^{\circ} 35^{\prime} \mathrm{E}$ ], $1500 \mathrm{~m}$ a.s.l., 1620-VII-1999 (D. E. Lomakin). - ALTAI TERRITORY: 1 male, 1 female (ISE), NE-Altai, 20-30 km E of Lake Teletskoe, South part of Abakansky Mt. Range, VII-1994 (E. T. Anisimov \& R. Yu. Dudko). - KEMEROVO AREA: 4 males, 1 female (ISE), 1 male, 1 female (ZMU), ca. $50 \mathrm{~km} \mathrm{~S}$ of Belogorsk, Kuznetskii Mt. Range, Chemodan Mt. [54 $42^{\prime} \mathrm{N}, 88^{\circ} 24^{\prime} \mathrm{E}$ ], 23-VII1992 (N. B. Demidenko); 2 males (ZMU), Gornaya Shoriya, ca. 10 km N of Shelegesh Vil., Pustag Mt. [52 $\left.58^{\prime} \mathrm{N}, 87^{\circ} 59^{\prime} \mathrm{E}\right], 1300-1500 \mathrm{~m}$ a.s.1, 13-26-VI-1999 (D. E. Lomakin).

Description. Male: Body as in Figs. 1A and 2A. Dorsum smooth except for presence of some denticles. Opening of scent gland pores not conspicuous but visible from above. Abdominal tergites, each with a transverse row of minute tubercles. Ocular tubercle (Fig. 1B-D), huge, occupies about a half of cephalothorax length at midline, crowned with numerous tubercles. Coxae of legs sparsely with minute spine-tipped tubercles and hairs. Abdominal sternites with scattered hairs (Fig. 2B). Genital operculum only with minute hairs.

Chelicera as in Figs. 1E-F, 3A, first segment distodorsally with some spines, second 


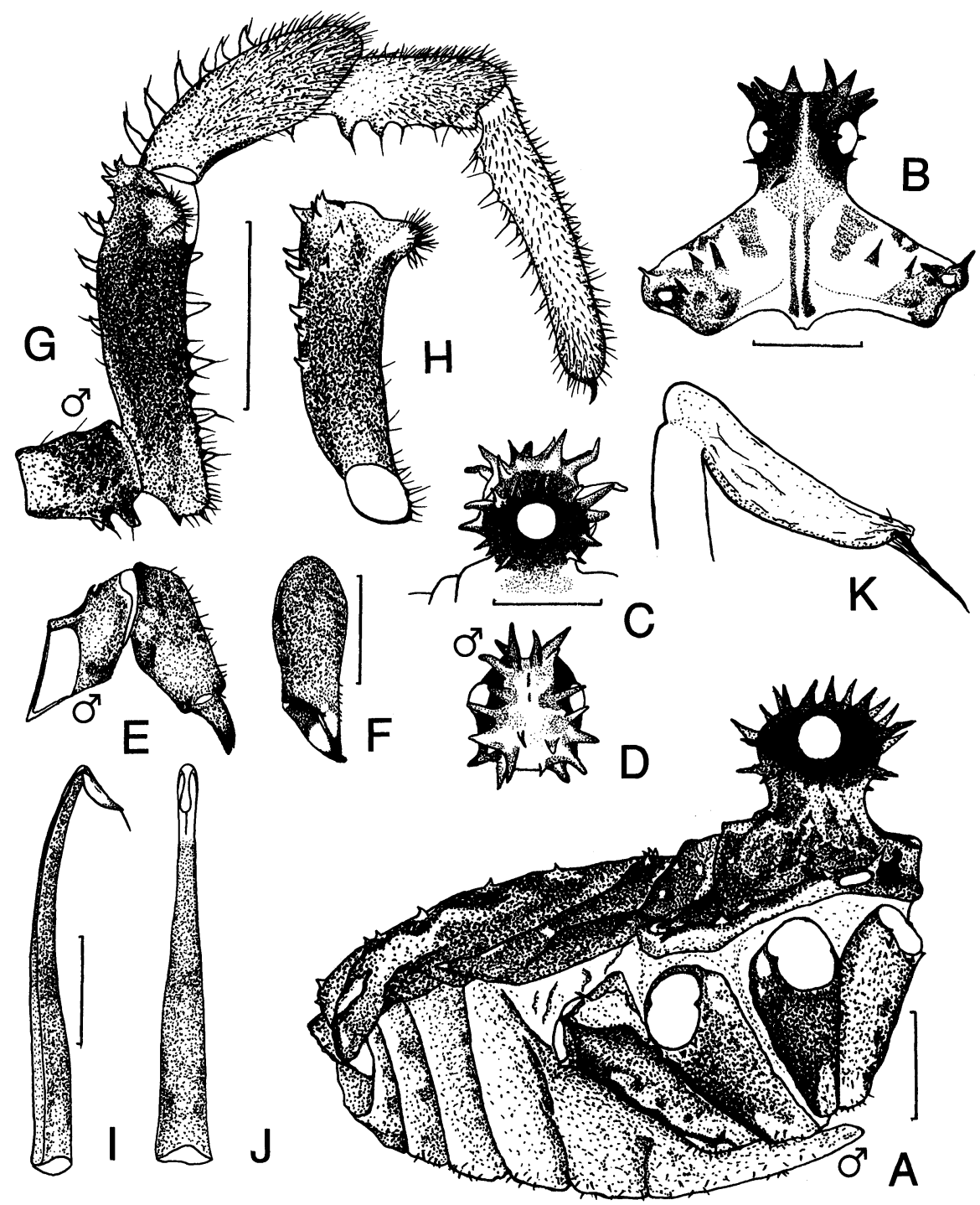

Fig. 1. Acanthomegabunus sibiricus n. sp. (holotype, male) - A, lateral view of body; B, frontal view of cepahlothorax. C-D, ocular tubercle: C, lateral view, D, dorsal view. E-F, right chelicera: E, ectal view; F, frontal view. $G$, mesal view of left palp; $\mathrm{H}$, ventral view of femur of right palp. I-K, penis: I, lateral view; J, dorsal view; K, lateral view of glans. Scales $=0.5 \mathrm{~mm}$.

segment dorsally and distomesally with sparse hairs (Fig. 3A).

Palp as in Figs. 1G-H, 3B-C; trochanter ventrally with a few tubercles; femur distomesally with a hump scattered with spines; ventrally and ditodorsally with prominent tubercles; patella distomesally with an apophysis densely covered with hairs and dorsally and laterally with prominent tubercles; tibia, dorsally, laterally, and ventrally, with three longitudinal rows of 3-4 tubercles; tarsus proximally with a ventral spine, 


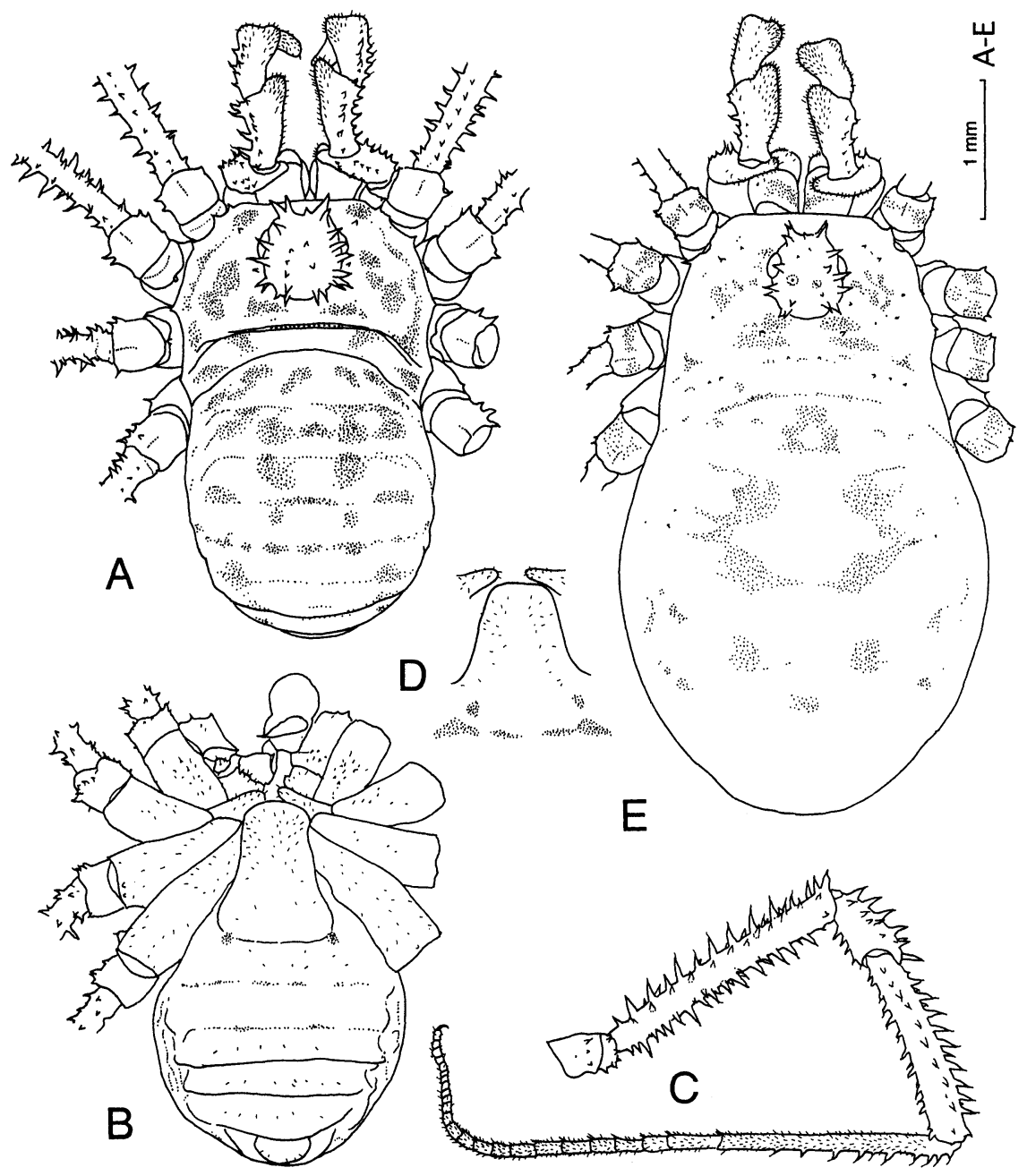

Fig. 2. Acanthomegabunus sibiricus n. sp. (A-C, male paratype; D-E, female paratype. Both from the type locality, Beliy Us R., Krasnoyarsk Prov.) — A, E, dorsal view of body; B, ventral view of body; D, ventral view of genital operculum; C, ectal view of right first leg.

ventromesally with an inconspicuous row of several black denticles at distal one thirds; claw smooth. Ectal surface of femur with a group of 5-6 pores (presumably of glandular function) near the basal joint.

Legs relatively short. Each segment round or slightly pentagonal or hexagonal in cross section; along the ridges, femora, patellae, and tibiae with longitudinal rows of erected hair-tipped spines. Number of rows of the spines: Femur $=5+1$ additional, patella and tibia $=5$. Metatarsus also dorsally with a single row of hair-tipped spines (Fig. 2C). Patella proximally with a spiracle on its ectal surface. Metatarsus and tarsal segments distoventrally with a pair of stout spines at the joint.

Penis as in Figs. $1 \mathrm{I}-\mathrm{K}$ and $4 \mathrm{~A}-\mathrm{B}, 2.1 \mathrm{~mm}$ long, $0.28 \mathrm{~mm}$ wide at base; shaft 

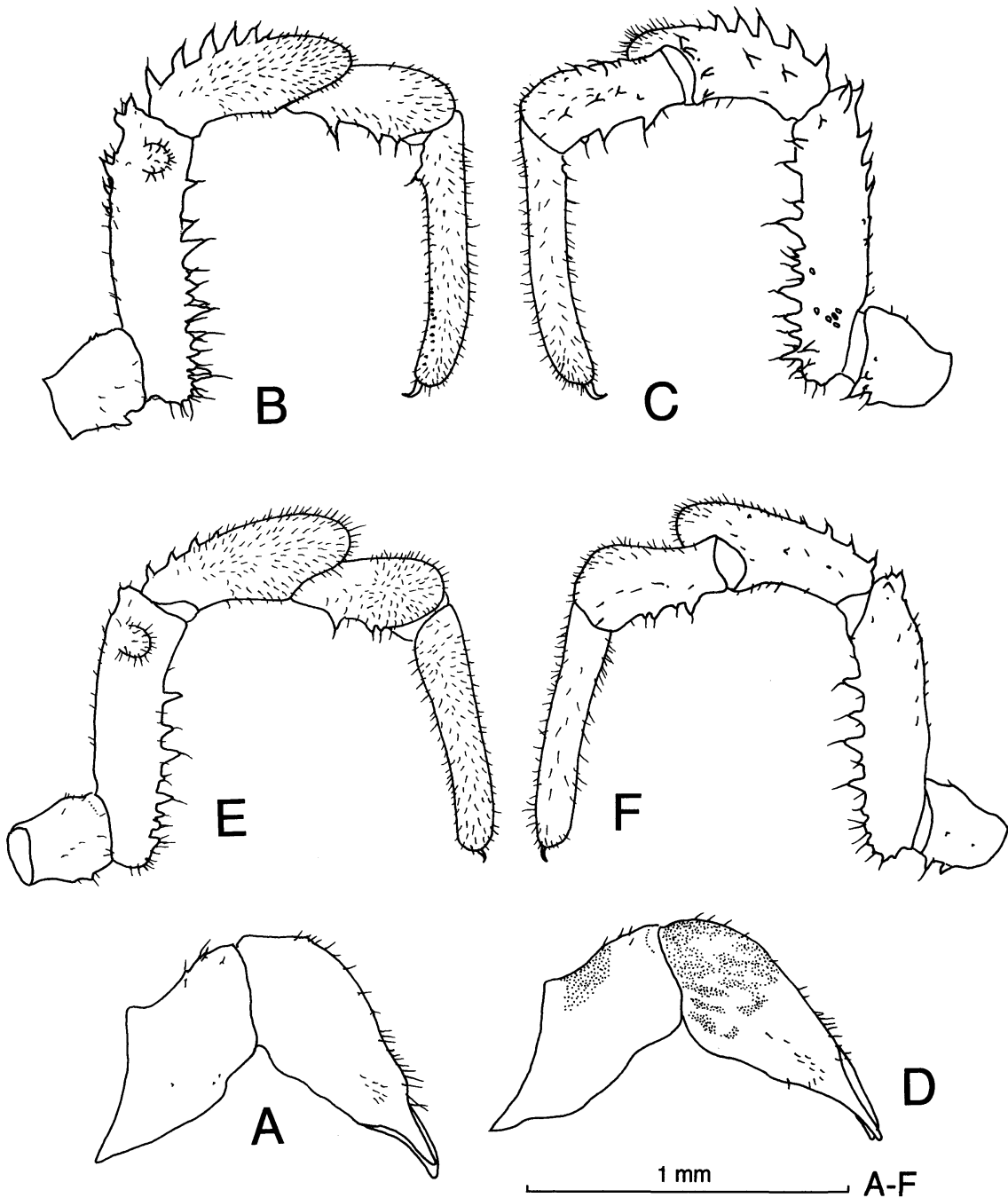

Fig. 3. Acanthomegabunus sibiricus n. sp. (A-C, male paratype; D-E, female paratype. Both from Beliy Us R., Krasnoyarsk Prov.) - A, D, mesal view of left chelicera; B, E, mesal view of left palp; C, F, ectal view of left palp.

gradually tapering toward tip, dorso-ventrally flattened at the distal half. Glans distally with two pairs of small spines. Internal muscle reaches about three fifths of the total length of the shaft from base.

Coloration: Body pale yellow speckled with brownish markings. Venter creamy yellow. Eye surrounded by a dark-colored ring.

Female: General appearance (Fig. 2E) same as in male, but with much swollen abdomen, proximally widened genital operculum (Fig. 2D) and paler coloration. Palp with less prominent ventral and dorsal spines. Palpal tarsus lacks a ventromesal row of denticles. Palpal femur without a group of pores on its ectal surface. Legs with 


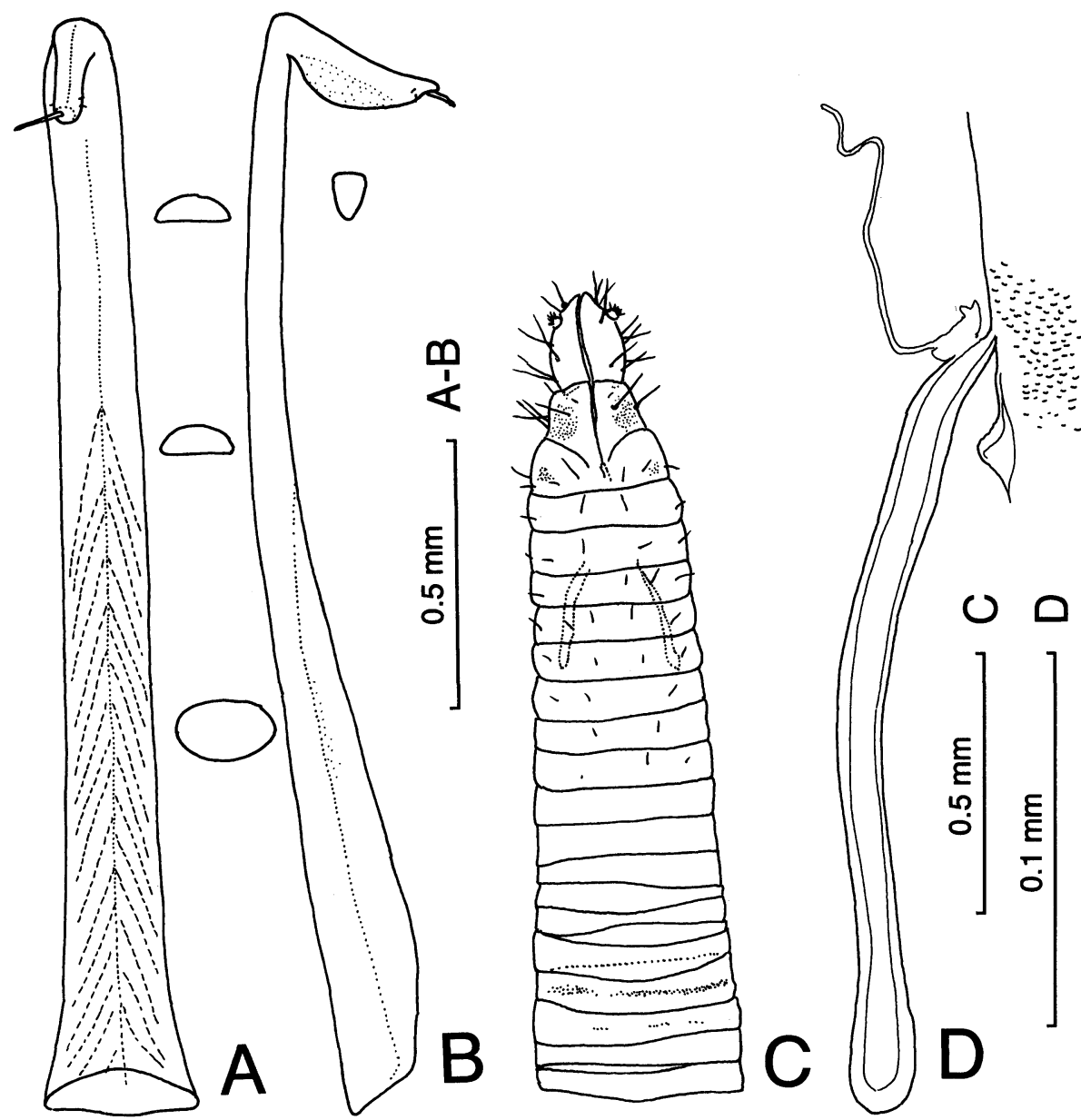

Fig. 4. Acanthomegabunus sibiricus n. sp. (A-B, male paratype; C-D, female paratype. Both from Beliy Us R., Krasnoyarsk Prov.) — A-B, dorsal (A) and lateral (B) views of penis with four cross sections of the shaft and glans (right); C, ovipositor; D, left seminal receptacle.

less-developed spines.

Ovipositor as in Fig. 4C, each of the second furcal joints with a slit sensillum per side. Seminal receptacle (Fig. 4D), situated between 2 nd to 5 th rings, elongated.

Measurements (in mm, male holotype and a female paratype from the type locality in parentheses). Total length of body 3.3 (4.0); Cephalothorax 1.1 (1.2) long; body width 1.7 (2.3); body height 1.8 (2.4). Distance between ocular tubercle and anterior margin of carapace $0.25(0.3)$. Ocular tubercle $0.6(0.6)$ wide, $0.5(0.6)$ high. Measurements of palpi and legs as in Table 1.

Distribution. The mountains of South Siberia; so far reported from the southern part of Krasnoyarsk Province, the Altai, Kemerovo Area and Khakassia, Russia (Fig. 5).

Habitat. This species can be collected in the mountain moss-stony tundra, moss 
Table 1. Length (in $\mathrm{mm}$ ) of palp and legs of male holotype, and a female paratype in parentheses of Acanthomegabunus sibiricus n. gen., n. sp.

\begin{tabular}{|c|c|c|c|c|c|c|}
\hline & $\mathrm{Fe}$ & $\mathrm{Pa}$ & $\mathrm{Ti}$ & $\mathrm{Mt}$ & $\mathrm{Ta}$ & Total \\
\hline Palp & $0.95(0.93)$ & $0.55(0.45)$ & $0.48(0.50)$ & - & $0.90(0.85)$ & $2.88(2.73)$ \\
\hline Leg I & $2.08(1.48)$ & $0.73(0.51)$ & $1.35(1.08)$ & $1.83(1.44)$ & $2.90(2.15)$ & $8.9(6.7)$ \\
\hline Leg II & $3.95(2.95)$ & $0.85(0.65)$ & $3.10(2.55)$ & $2.90(2.30)$ & $4.70(3.75)$ & $15.5(12.2)$ \\
\hline Leg III & $2.30(1.58)$ & $0.70(0.55)$ & $1.55(1.20)$ & $2.25(1.75)$ & $3.00(2.50)$ & $9.8(7.6)$ \\
\hline Leg IV & $3.40(2.63)$ & $0.75(0.70)$ & $2.30(1.78)$ & $3.40(3.05)$ & $4.75(3.15)$ & $14.6(11.3)$ \\
\hline
\end{tabular}

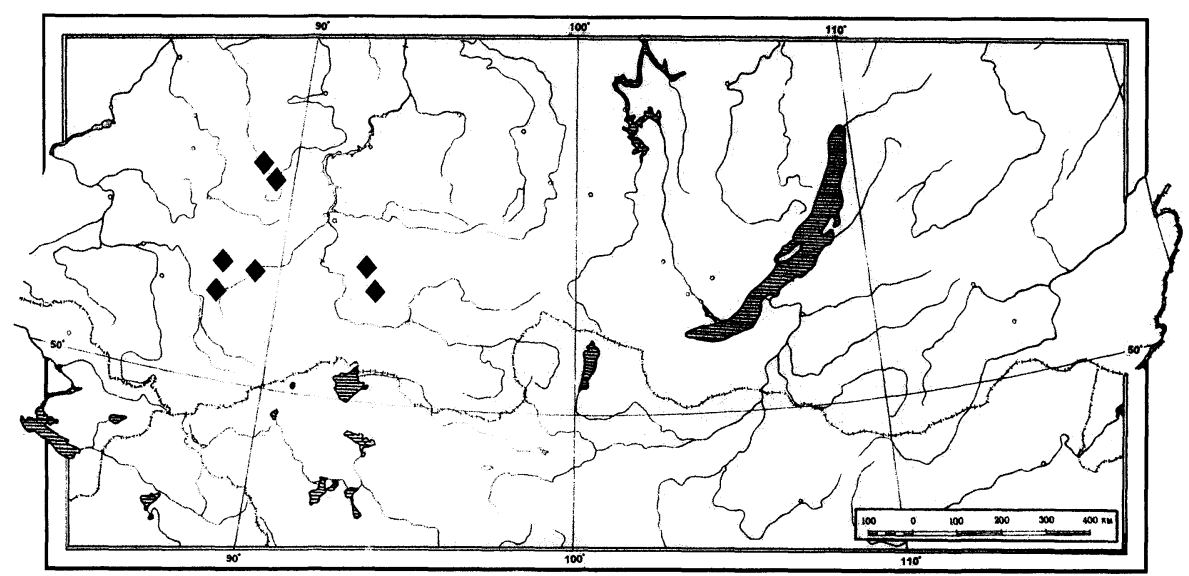

Fig. 5. Records of Acanthomegabunus sibiricus n. sp. in Siberia.

pebble banks of rivers, Abies forest, Anemone meadows, stony debris and in crowns of coniferous trees. inhabits.

Etymology. The specific epithet refers to Siberia, the area where this species

\section{Genus Homolophus Banks 1893}

Homolophus Banks 1893, p. 208 (Type species: Homolophus arcticus Banks 1893); Cokendolpher 1987, p. 89.

Euphalangium Roewer 1911, p.33 (in part) (Type: Euphalangium nordenskioeldi (L. Koch)); Starega 1964, p. 390 (in part); Starega 1978, p. 223 (in part); Silhavy 1972, p. 101 (in part).

Diagnosis. A group of Phalangiinae species characterized by having: 1) relatively large body (length usually $8-9 \mathrm{~mm}$, more than $5 \mathrm{~mm}$ at least); 2) a crest-like mound comprised of numerous black-tipped tubercles on preocular area of cephalothorax (less developed in female; cf. fig. 2 in Tsurusaki 1987) ; 3) smooth coxae (only with sparse hairs); 4) chelicerae with blackish brown tabby splotches, showing sexual dimorphism (conspicuously larger in males); 5) short and robust palpi, whose femora, patella, tibiae with numerous black-tipped tuberckes, in males; and 6) short legs (first femur shorter than body length: often less than two thirds of the latter) with sexual dimorphism (first legs especially thicker in males).

Remarks: A total of 11 species of Homolophus have so far been recorded from 
Russia (Siberia), Mongolia, and China (Cokendolpher 1987; Tsurusaki \& Song 1998): H. albofasciatus (Kulczynski 1901); H. arcticus Banks 1893 (For detailed description see Tsurusaki 1987); H. betpakdalensis (Gricenko 1976); H. nordenskioeldi (L. Koch 1879) (see Tchemeris et al. 1998), H. potanini (Simon 1895)(see, below), H. przewalskii (Starega 1978), H. suzukii (Silhavy 1972), H. thienshanensis (Silhavy 1967), H. tibetanus (Roewer 1911), H. vladimirae (Silhavy 1967), H. hunan (Zhu et al. 1999). However, taxonomic history of the genus has been in quite a mess (cf. Cokendolpher 1987). This is partly due to tremendous variability of body size, coloration, and external characters of the group both within and between populations, and partly due to poor descriptions of male genitalia, which seems to be the only reliable diagnostic character in species identification of the group. To avoid further confusion, the genus has above been redefined. Under this definition, following two species hitherto included in the genus (Homolophus or Euphalangium) are to be removed from the genus: Homolophus potanini (Simon 1895) sensu Starega (1978) and Euphalangium transbaicalicum (Kulczynski 1901) sensu Starega (1964) and Silhavy (1972). We present some notes on these species, together with those on two additional species (one of which is new) of the Homolophus below.

Homolophus gobiensis n. sp.

(Figs. 6-8)

Specimens examined. Holotype: male (ZMU), MONGOLIA, South Gobi Aimak, $15 \mathrm{~km}$ west of

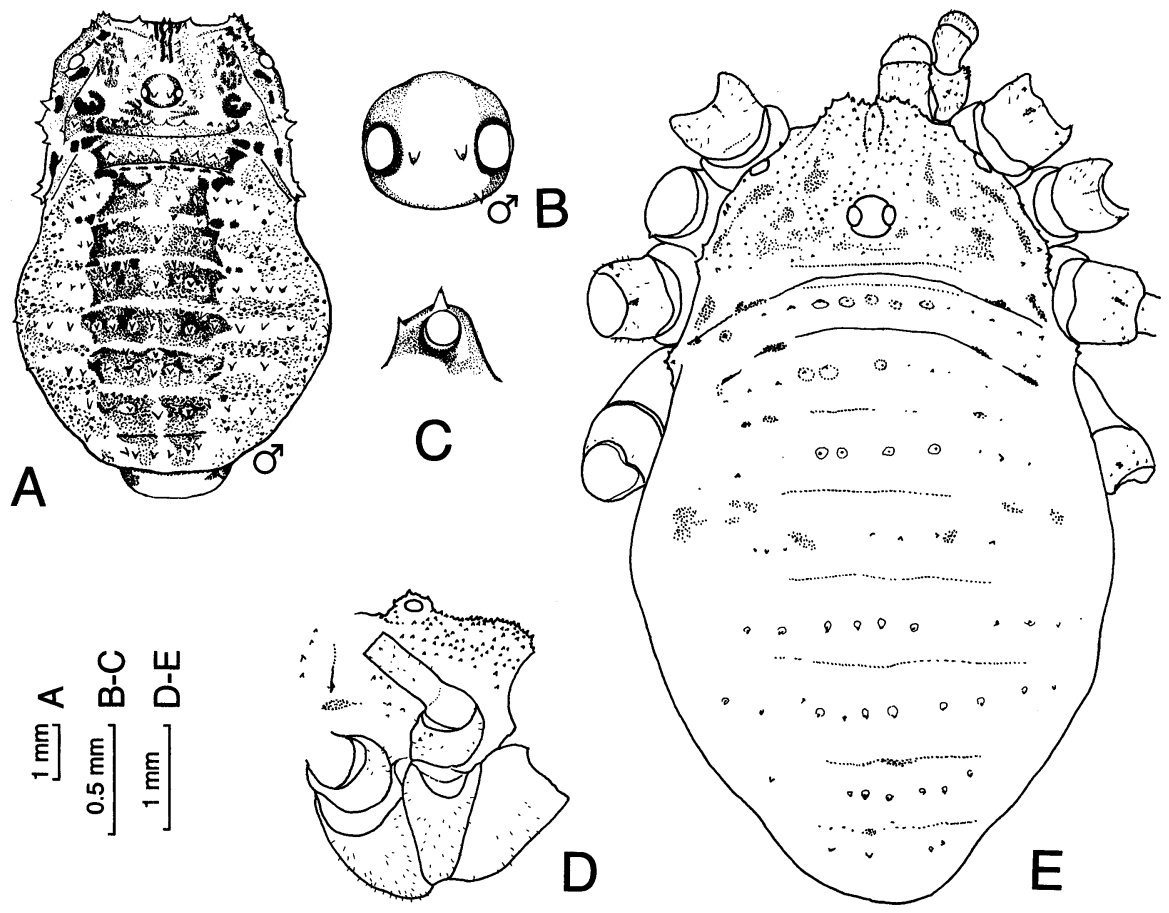

Fig. 6. Homolophus gobiensis n. sp. (A-C, male holotype; D-E, female paratype; both from South Gobi Aimak, Mongolia) _ A, E, dorsal view of body; D, lateral view of front half of body; B-C, dorsal (B) and lateral (C) view of ocular tubercle. 


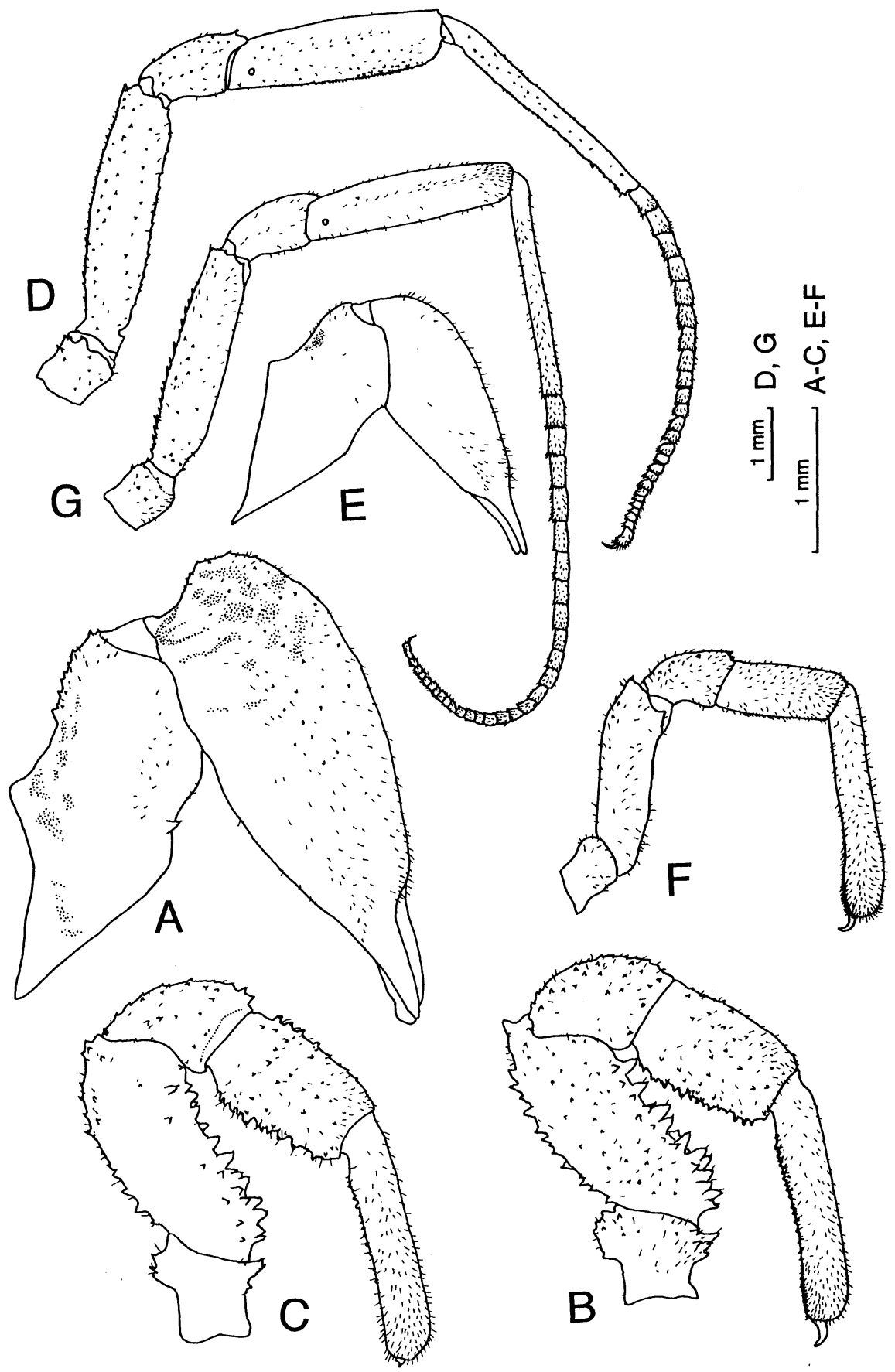

Fig. 7. Homolophus gobiensis n. sp. (A-D, male holotype; E-G, female paratype; both from South Gobi Aimak, Mongolia) _— A, E, mesal view of left; B, F, mesal view of left palp; C, ectal view of right palp; D, G, ectal view of right first leg. 


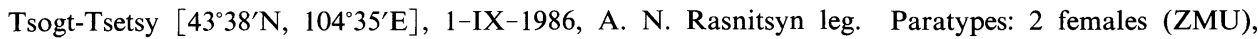
together with holotype.

Diagnosis. Conspicuously widened and flattened penis serve to separate this species from all the other congeners of Homolophus. Conspicuously short legs in this species (ratio of length of leg femur I to body length $=$ ca. 0.4 in both sexes) may also characterize this species in the genus.

Description. Male: Large harvestman, of the form as shown in Fig. 6A. Supracheliceral lamellae very low, not visible from above. Preocular area of cephalothorax with a mound consisted of several black-tipped denticles. Ocular tubercle not canaliculate above, only with a few denticles. Thoracic tergites I, II, and abdominal tergites I-VII, each with a transverse row of black-tipped denticles encompassed by creamy white rings. Coxae I-IV unarmed, smooth, with scattered hairs only. Genital operculum also with sparse hairs only.

Chelicera (Fig. 7A) short and robust; basal joint distodorsally with several denticles; distal joint also with several sparse denticles.

Palp (Fig. 7B-C) rather short and thick; trochanter distodorsally and distoventrally with some tubercles; femur ventrally with several well-developed tubercles and dorsally and laterally covered with numerous tubercles; patella distally thickened, dorsally and laterally with numerous tubercles; tibia swollen, proximally widened, with many tubercles and black bristles on all sides, especially dense ventrally; tarsus hairly, ventrally with dense rows of dark-colored denticles, which extend from proximal one-fifth to a half, claw smooth.

Legs relatively short; femora to tibiae thickened, especially so in legs I and III. Each segment cylindrical or slightly pentagonal or hexagonal in cross section. Femora, patellae, and tibiae with many denticles, especially dense on distoventral surfaces of tibiae of first legs (Fig. 7D). Tibia laterally with a spiracle near its basal joint.

Penis (Fig. 8A-B). Shaft $3.0 \mathrm{~mm}$ long, dorso-ventrally flattened, widest at middle portion ( $0.69 \mathrm{~mm}$ wide). Glans, $0.40 \mathrm{~mm}$ long, $0.21 \mathrm{~mm}$ wide at widest portion; ventrally convex and forming a blunt ridge. Stylus $0.10 \mathrm{~mm}$ long.

Coloration: Body ground color yellowish brown; with many dark brown specks and splotches. Eye tubercle above light yellowish brown, with dark-colored eye rings. Chelicera dark brown; both lateral sides of distal joint with conspicuous black brown tabby blotches (Fig. 7A). Legs dark to blackish brown; metatarsi and tarsi slightly lighter.

Female: Form and coloration as in male (Fig. 6D-E), except chelicera and legs I, III less developed (Fig. 7E-G). Chelicera (Fig. 7E) lacks dorsal denticles on basal joint. Armament of palp very weak, only with some denticles on femur and patella (Fig. 7F). Ovipositor (Fig. 8C) second furcal joint with a slit sensillum per side. Each segment strongly stained with dark brown pigments. Seminal receptacles, as in Fig. 8D, located within 1 st to 3rd ovipositor rings, with two elongated atria.

Measurements (in mm: holotype male; 2 female paratypes in parentheses). Total length of body 8.86 (8.93-8.90). Cephalothorax 2.8 (2.5-3.1) long, 4.5 (5.1) wide; Abdomen 5.3 (5.6) wide; distal segment of chelicera 3.53 (2.04-2.80). Length of palpi and legs as in Table 2.

Distribution. So far known from the type locality alone.

Etymology. The specific epithet refers to the locality name.

Remarks. The present species is easily distingushed by its extremely widened shaft of penis from any other congeners. However, none of these Homolophus species has been found sympatrically with other congeneric species, though their distributional 

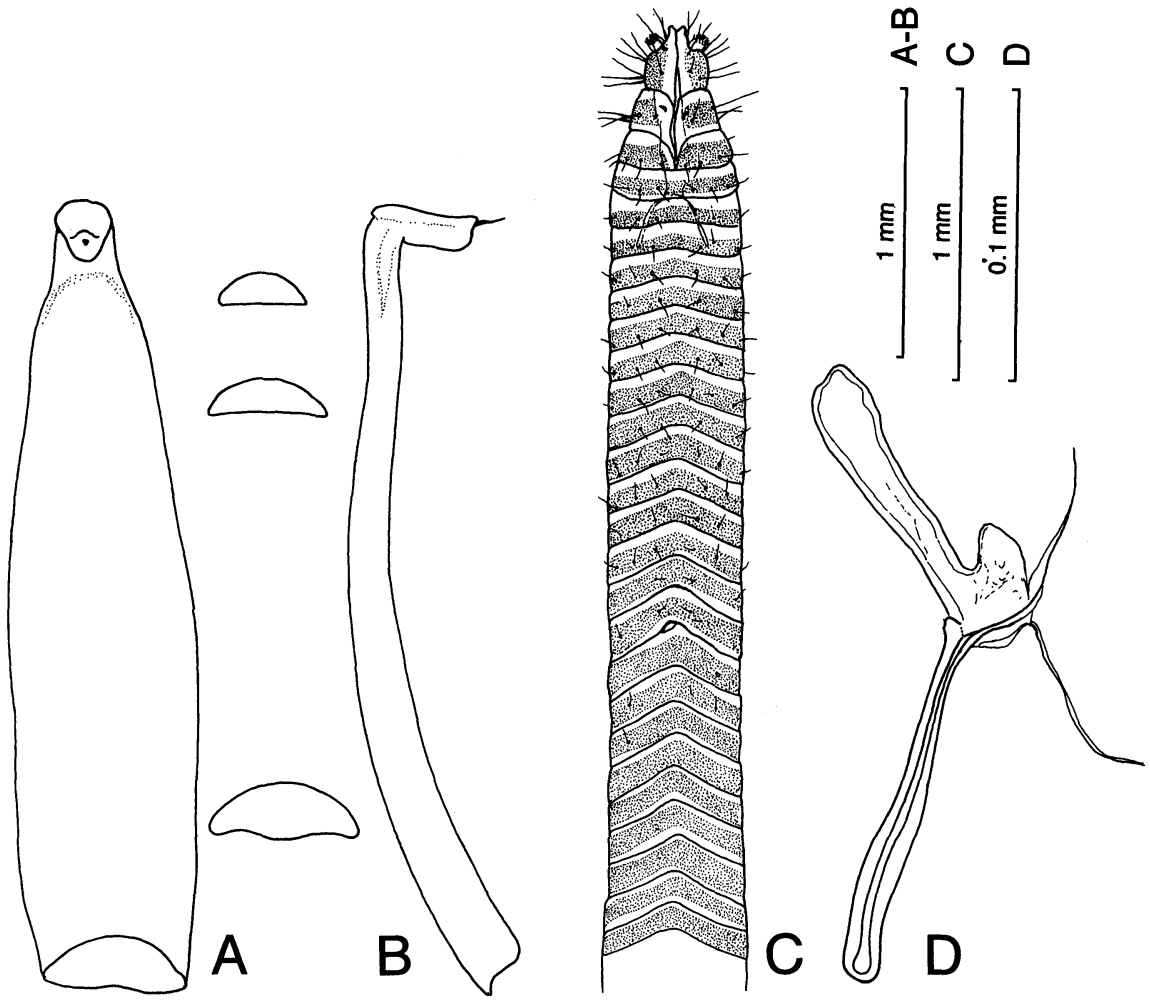

Fig. 8. Homolophus gobiensis n. sp. (A-B, male holotype; C-D, female paratype; both from South Gobi Aimak, Mongolia) _ A-B, dorsal (A) and lateral (B) views of penis with three cross sections of the shaft; $C$, ventral view of ovipositor; $D$, left seminal receptacle.

Table 2. Length (in $\mathrm{mm}$ ) of palp and legs of male holotype and a female paratype in parentheses of Homolophus gobiensis n. sp.

\begin{tabular}{lcccccc}
\hline & $\mathrm{Fe}$ & $\mathrm{Pa}$ & $\mathrm{Ti}$ & $\mathrm{Mt}$ & $\mathrm{Ta}^{1)}$ & Total \\
\hline Palp & $1.45(1.18)$ & $1.02(0.61)$ & $1.11(0.80)$ & - & $1.71(1.66)$ & $5.28(4.24)$ \\
Leg I & $3.49(3.24)$ & $1.60(1.45)$ & $2.74(2.80)$ & $3.62(3.18)$ & $5.61(6.72)$ & $17.1(17.4)$ \\
Leg II & $6.20(6.12)$ & $2.00(1.89)$ & $4.89(5.13)$ & $4.40(4.30)$ & $10.40(13.93)$ & $27.9(31.4)$ \\
Leg III & $3.61(3.30)$ & $1.86(1.60)$ & $2.90(2.71)$ & $4.20(3.99)$ & $6.30(6.99)$ & $18.9(18.6)$ \\
Leg IV & $5.03(5.30)$ & $1.81(1.83)$ & $4.01(3.96)$ & $6.00(5.42)$ & $?(11.89)$ & $?(28.4)$ \\
\hline
\end{tabular}

1) Length of tarsus of the fourth leg of the holotype cannot be measured due to loss of the tip.

ranges appear to overlap to some extent at least between some species (e.g. between $H$. arcticus and $H$. gobiensis). Further detailed information on their distribution is needed to clarify their taxonomic and evolutionary relationships.

\section{Homolophus pallens (Kulczynski 1901) new combination}

Phalangium pallens Kulczynski 1901, p. 361. (Type locality: Tuguruk, Mongolia [now Mongolia, Gobi-Altai Aimak, Tugreg [=Tuguruk], ca. $\left.45^{\circ} 50^{\prime} \mathrm{N}, 94^{\circ} 59^{\prime} \mathrm{E}\right]$ ) 
Euphalangium transbaicalicum: Starega 1964, p. 1964 (in part), fig. 18-19.

Opilio pallens: Roewer 1911, p. 41, fig. 8 in plate 3; Roewer 1912, p. 136, fig. 23 in plate 3; Roewer 1923, p. 776, fig. 949.; Roewer 1956, p. 293 (China SMF \# 4750, examined)

Homolophus przewalskii (nec Starega, 1978): Tchemeris et al., 1998, figs. 8-14.

Remarks. Due to our recent lapse, the records and description of this species were inadvertently presented under the name of $H$. przewalskii in our first paper (Tchemeris et al. 1998). It is amended here as Homolophus pallens (Kulczynski). This species was. first described as Phalangium pallens by Kulczynski (1901) and later transferred to Opilio by Roewer (1911). Starega (1964) treated it as a junior synonym of Euphalangium transbicalicum (or Egaenus bidens in Starega 1978) and it was followed by Silhavy (1972). However, one of us (N.T.) ascertained a male specimen labeled "Opilio pallens (Kulczynski) \#4750, S. Mongoliet, Roewer det 1933" in the Senckenberg Museum, Frankfurt, to possess typical features of Homolophus and to be not conspecific with Bidentolophus bidens (=Euphalangium transbicalicum) by having the smooth coxae and genital operculum. The penis as well as the other external features of the material presented in our former paper (Tchemeris et al. 1998) corresponds well with that of the "Opilio pallens (Kulczynski) \# 4750" specimen, hence it is highly probable that they are conspecific. We are not sure that the specimen \# 4750 is truly conspecific with the original specimen of "Phalangium pallens", on which Kulczynski's description was based, since we have not checked the latter specimens. However, we provisionally treat it as "Homolophus pallens".

This species is distributed in the area extending from middle part of Mongolia to Tuva, southern Siberia.

In both distributional ranges and shape of penis, this species appears to show a condition intermediate between Homolophus nordenskioeldi and $H$. arcticus which mainly inhabit in eastern part of Siberia.

\section{Opilio potanini (Simon 1895) new combination}

Phalangium Potanini (sic) Simon 1895, p. 344 (Type: Tschorny-Irtysch, Ust-Kamenogorsk [Kazakhstan, East-Kazakhstan Area, Zaisan District ?, bank of Cherny Irtysh River, ca. $\left.47^{\circ} 57^{\prime} \mathrm{N}, 85^{\circ} 04^{\prime} \mathrm{E}\right]$ )

Opilio almasyi Roewer 1911, p. 44 (Type: Tekkes and Ala-Buga, Kazakhstan [Kazakhstan, Almaty

Area, Raiymbek Distr., Tekes (ca. $42^{\circ} 50^{\prime} \mathrm{N}, 80^{\circ} 03^{\prime} \mathrm{E}$ ) and Kyrghyzstan, Naryn Area, Ak-Talinsky

Distr., Alabuga River (ca. $41^{\circ} 14^{\prime} \mathrm{N}, 74^{\circ} 30^{\prime} \mathrm{E}$ )]); Roewer 1912, p. 132; Roewer 1923, p. 774, fig. 947:

Redikorzev 1936, p. 33; Roewer 1956, p. 280; Silhavy 1967, p. 475, fig. 14; Gricenko 1979, p. 35, fig. 28)

Euphalangium potanini: Starega 1978;

Opilio asiaticus Gricenko 1979, p. 37, fig. 29. New synonymy

Opilio asiaticus: Tchemeris et al, 1998, p. figs. 32-42.

Homolophus potanini: Cokendolpher 1987, p. 92.

Specimens examined. KAZAKHSTAN: Almaty Area: 7 males, 4 female (ISE), near Almaty, Medeo [ca. 43 ${ }^{\circ} 17^{\prime} \mathrm{N}, 7^{\circ} 57^{\prime}$ ], 3-28-VII-1997 (A. V. Gromov). - E-Kazakhstan Area: 1 male (ISE), Serebryansk, 9-10-VII-1996 (V. K. Zinchenko). - RUSSIA: Altai Territory: 1 male, 1 female (ISE), Ongudai Distr., Chike-Taman Pass $\left[50^{\circ} 38^{\prime} \mathrm{N}, 8^{\circ} 19^{\prime} \mathrm{E}\right]$, 23-VII-1998 (I. I. Volonikhina). For other material examined see Tchemeris et al. (1998).

Remarks. Redescription of the species was earlier presented under the name of "Opilio asiaticus Gricenko" in Tchemeris et al. (1998). Diagnostic character of Opilio asiaticus from $O$. almasyi Roewer alleged by Gricenko (1979) cannot be considered sufficient for the separation. On the other hand, Opilio almasyi redescribed by Silhavy 
(1967) was considered a junior synonyn of Euphalangium (now Homolophus) potanini (Simon), which was originally described under Phalangium, by Starega (1978). We provisionally follow the Starega's treatment that "Opilio almasyi" and E. potanini are conspecific. However, this species should not be treated under Homolophus because of possessing very long legs (first femur at least longer than body; often more than 1.5 times of body length), legs are covered with numerous sharp-pointed spines, and first pair of legs not swollen. We tentatively treat it under Opilio, though its validity have to be tested by further detailed examinantion.

\section{Bidentolophus bidens (Simon 1880)}

Acantholophus bidens Simon 1880, p. 126.

Bidentolophus bidens: Roewer 1912, p. 82; 1923, p. 744, fig. 923; Tsurusaki \& Song 1998, p. 526, fig. 47 in p. 162.

Euphalangium transbaicalicum (in part): Starega 1964; Silhavy 1972, p. 102 (figs. 1-8)

Egaenus bidens: Starega 1978, p. 221

Other references not required here.

Remarks: This species had long been known under the name of "Euphalangium transbaicalicum" (Starega 1964, Silhavy 1972), though Starega (1978) finally treated it as "Egaenus bidens (Simon)". It was Roewer (1911, 1912, 1923, 1956) who first transferred the Phalangium nordenskiöldi var. transbaicalica to Euphalangium. However, an inspection by N.T. of the Roewer's material (RI/7/689) described as 1 male and 1 female from Selenga [River], Buryatia, Siberia (Roewer 1911, 1912, 1923, 1956) preserved in the Senckenberg Museum revealed that actually they are not "Bidentrophus bidens" but "two males of Homolophus nordenskioeldi".

This species has coxae and trochanters with numerous sharp-pointed tubercles. Moreover, the preocular mound on the cephalothorax bears many tubercles protruded anteriorly (cf. Tsurusaki \& Song 1998, p. 162, fig. 3). These and other characters of the species are quite different from those of Egaenus convexus (C. L. Koch 1835), type species of the genus Egaenus (cf. Martens 1978). A detailed redescription of the genus and species will be published elsewhere.

\section{Acknowledgments}

We are grateful to Dr. K. G. Mikhailov, of the ZMU, for giving access to the opilionid materials from Mongolia under his care. Besides, Drs R. Yu. Dudko, V. K. Zinchenko and I. I. Volonikhina (all Novosibirsk, Russia), Mr. D. E. Lomakin (Tyumen, Russia), Mr. A. V. Gromov (Almaty, Kazakhstan) and Ms. N. B. Demidenko (Belogorsk, Russia) are much obliged form giving us their opilionid collections for the present study. One of us (N.T.) thanks Drs. J. Martens and M. Grasshoff for their help in examining many Chinese and Mongolian specimens preserved in the Senckenberg Museum, Frankfurt, during his stay in Mainz in 1993; and Dr. D.-X. Song for offering an opportunity to check many Chinese materials at the Museum of Zoological Institute, Chinese Academy of Sciences, Beijing in 1991. Access to these museum materials was indispensable to delimit range of variation within each species of Homolophus. Thanks are also extended to Dr. L. Klimes (Trebon, Czech Republic), who called our attention to some errors of species names in our first paper, and to Drs. O. Gorlova and I. G. Gorlov (Novosibirsk, Russia), who provided English translations of some Russian papers for N.T. Finally, we are thankful to Mr. A. V. Gromov (Almaty, Kazakhstan) for the help in decoding old geographical names from Middle Asia, and to Dr. Hiroshi Abé for his suggestion on the manuscript.

\section{References}

Banks, N. 1893. The phalanginae of the United States. Canadian Entomol., 25: 205-211. 
Cokendolpher, J. C. 1987. On the identity of the genus Homolophus: A senior synonym of Euphalangium (Opiliones: Phalangiidae). Acta Arachnol., 35: 89-96.

Gricenko (Gritsenko), N. I. 1979. [The harvestmen (Opiliones) from the Asian part of the USSR].pp. 28-38. In: Yu. S. Balashov (ed.) The Fauna and Ecology of Arachnida. Academy of Sciences of the USSR. Proceedings of the Zoological Institute. (In Russian).

Kulczynski, V. 1901. Arachnoidea. In: G. Horvath, Zoologische Ergebnisse der dritten asiatischen Forschungs reise des Grafen Eugen Zichy. Budapest - Leipzig

Martens, J. 1978. Weberknechte, Opiliones. Die Tierwelt Deutschlands. 64 Teil., Gustav Fischer, Jena. $464 \mathrm{pp}$.

Redikorzev, V. V. 1936. Materials to the fauna of Opiliones of the USSR. Trav. Inst. Zool. Acad. Sci. URSS., 3: 33-57. (In Russian with German summary)

Roewer, C. F. 1911. Übersicht der Genera der Subfamilie der Phalangiini der Opiliones Palpatores nebst Beschreibung einiger neuer Gattungen und Arten. Arch. Naturg., 77 (Suppl.2) : 1-106. T. 13.

Roewer, C. Fr. 1912. Revision der Opiliones Palpatores. II. Teil. Familie der Phalangiidae (Subfamilien: Sclerosomatini, Oligolophini, Phalangini). Arch. naturw. Ver., Hamburg, 20: 1-295. T. 14.

Roewer, C. F. 1923. Die Weberknechte der Erde. Gustav Fischer, Jena. 1116pp.

Roewer, C. F. 1956. Über Phalangiinae (Phalaniinae, Opiliones Palpatores). (Weitere Weberknechte XIX). Senckenbergiana biol., 37: 247-318.

Silhavy, V. 1967. Beitrag zur Kenntnis der Weberknechte-Fauna des sowjetischen Znetral-Asien (Arach., Opilionidea). Acta Ent. Bohemosl., 64: 472-478.

Silhavy, V. 1972. Asiatische Arten der Gattung Euphalangium Roewer (Arachnida: Opiliones: Phalangiidae). Senckenbergiana Biol., 53: 101-108.

Simon, E. 1880. Etudes Arachnologiques. 11e Memoire. 17. Arachnides recueilles aux environs de Pekin. Ann. Soc. Entomol. France, ser. 5, 10: 97-128.

Simon, E. 1895. Arachnides recueillis par Mr. G. Potanine en Chine et en Mongolie (1876-1879). Bull. Acad. imp. Sci., St. Pétersbourg, Ser. 5, 2: 331-345.

Starega, W. 1964. Materialien zur Kenntnis der ostasiztischen Weberknechte (Opiliones). I-IV. Ann. Zool., Warszawa, 22: 387-410.

Starega, W. 1978. Katalog der Weberknechte (Opiliones) der Sowjet Union. Fragmenta Faun., 23: 197-241.

Tchemeris, A. N., Logunov, D. V. \& Tsurusaki, N. 1998. A contribution to the knowledge of the harvestman fauna of Siberia (Arachnida: Opiliones). Arthropoda Selecta, 7: 189-199

Tsurusaki, N. 1987. Two species of Homolophus newly found from Hokkaido, Japan (Arachnida: Opiliones: Phalangiidae). Acta Arachnol., 35: 97-107.

Tsurusaki, N. \& Song, D.-X. 1998. Order Opiliones. pp. 155-167+522-526. In: Yin, W. Y. (ed.) Pictorial Keys to Soil Animals. Science Press, Beijing, 757pp. (In Chinese)

Zhu, M., Song, D. \& Kim. J. P. 1999. Notes on three species of the genus Homolophus (Opiliones: Phalangiidae) from China. Korean Arachnol., 15: 7-12.

(Received March 27, 2000/Accepted April 13, 2000) 
た。本種は沖縄本島に固有で，石灰洞にのみ発 見される。個体群密度は非常に低い。これまで 雌のみしか採集されておらず，また，雌の外雌 器や交尾口の退化は, 本種が単為生殖をおこな っている可能性を強く示唆する. 本種は洞穴内 での生活に適応的とみられる形質を他にもいく つか備える. 琉球列島の地史に関連して, 洞穴 という生息場所への特化について議論した。

日本産アシダカグモ科, I. ミナミアシダカグモ 属(新称), アシダカグモ属, コアシダカグモ属 (新称)の 4 新種の記載および既知種についての 知見（クモ目：アシダカグモ科：ツユグモ亜科 およびアシダカグモ垔科)（pp. 41-60)

P. Jäger ${ }^{1}$ ・ 小野展嗣 ${ }^{2}$ ('Institut für Zoologie, Johannes Gutenberg-Universität, Germany ; ${ }^{2} \mathbf{T} 169$ -0073 東京都新宿区百人町 3-23-1 国立科学 博物館動物研究部)

日本産アシダカグモ科の Olios [ミナミアシダ カグモ属 (新称) ] の 1 新種, Heteropoda [アシ ダカグモ属］の 1 新種ならびに Sinopoda [コア シダカグモ属 (新称) ] の 2 新種の計 4 新種を以 下のように命名して記載した：Olios japonicus sp. nov. [ニホンミナミアシダカグモ (新称)], Heteropoda simplex sp. nov. [ホソミアシダカグ モ (新称, 細身の意)] Sinopoda okinawana sp. nov. [リュウキュウコアシダカグモ (新称) ], Sinopoda tanikawai sp. nov. [アマミコアシダカ グモ (新称)]. ミナミアシダカグモ属は日本か ら新たに記録された。そのほか, 本科のいくつ かの既知種について若干の分類学的知見と採集 記録を付記し, 日本産の亜科および属の特徴に ついて解説を加えた。

大陸アジア南部からのアシダカグモ亜科（アシ ダカグモ科) の 2 新属（pp. 61-71）

P. Jäger (Institut für Zoologie, Johannes Gutenberg-Universität, Germany)

大陸アジア南部からのアシダカグモ亜科（ア シダカグモ科）の 2 新属Pseudopoda と Bhutaniella を記載した。 それぞれPseudopoda prompta (O. P.-Cambridge 1885) と Bhutaniella hillyardi を模式種として指定し，記載した。 Heteropoda 属として記載されていた次の種は Pseudopoda に転属させた：P. casaria (Simon 1897), P. exigua (Fox 1938), P. exiguoides (Song \& Zhu 1999), P. grahami (Fox 1936), P. lushanensis (Wang 1990), P. virgata (Fox 1936), $P$. zhangmuensis (Hu \& Li 1983), P. zhejiangensis (Zhang \& Kim 1996). また, Heteropoda sikkimensis Gravely 1931 Bhutaniellaに移し た.両属とも分布は標高 $1000 \mathrm{~m}$ 以上の高所に限 られているようである。（和訳：編集委員会）

シベリアとモンゴルからのザトウムシの 2 新種 (1 新属) とウデブトザトゥムシ属の再定義（マ ザトウムシ科）（pp. 73-86）

鶴崎展巨 ${ }^{1}$, A. N. Tchemeris ${ }^{2}, \&$ D. V. Logunov ${ }^{3}$ ( ${ }^{1}$ T680-8551 鳥取市湖山町南 4-101 鳥取大 学教育地域科学部生物学教室; ${ }^{2}$ Dept. Invertebrate Zool., Fac. Biol. \& Soil Sci. Tomsk State University, Tomsk, Russia ; ${ }^{3}$ Zool., Mus., Biol. Instit. Siberian Div. Russ. Acad. of Sci., Novosibirsk, Russia)

シベリアからマザトウムシ科の Acanthomegabunus sibiricus を新属新種として，また， モンゴル南ゴビ地方からウデブトザトウムシ属 の 1 種 Homolophus gobiensis を新種として記載 した. ウデブトザトウムシ属については再定義 を与え, Phalangium pallens Kulczynski を本属 に,また Homolophus potanini を Opilio 属に移 した. Opilio asiaticus Gricenko は Opilio potanini (Simon) の後行異名とした.

シベリア南部からのウデザトウムシScleropilio insolens の再記載とウデザトウムシ属の 改訂 (pp. 87-94)

鶴崎展巨 ${ }^{1}$, A. N. Tchemeris, \& D. V. Logunov ${ }^{3}$ ( ${ }^{1}$ T680-8551 鳥取市湖山町南 4-101 鳥取大 学教育地域科学部生物学教室 ; ${ }^{2}$ Dept. Invertebrate Zool., Fac. Biol. \& Soil Sci. Tomsk State University, Tomsk, Russia ; ${ }^{3}$ Zool. Mus., Biol. Instit. Siberian Div. Russ. Acad. of Sci., Novosibirsk, Russia) 